\title{
Socioenvironmental Management, the Denial of Theory U and the Amazon Rainforest Fires
}

\author{
Fernanda Rodrigues de Siqueira ${ }^{1}$, Flavio de Sao Pedro Filho ${ }^{2}$, Irene Yoko Taguchi Sakuno ${ }^{3} \&$ Vinicius de Oliveira \\ Pinheiro ${ }^{4}$ \\ ${ }^{1}$ Federal University of Rondônia (UNIR), Brazil \\ ${ }^{2}$ Management and Economics (UBI), Covilhã, Portugal. PPGA and PROFIAP / Federal University of Rondônia, \\ Brazil. \\ ${ }^{3}$ Political Science, Federal University of Rio Grande do Sul (UFRGS), Brazil \\ ${ }^{4}$ Center of Ji-Paraná, Lutheran University, Brazil \\ Correspondence: Flávio de São Pedro Filho, Post-Doctorate, Management and Economics (UBI), Covilhã, Portugal. \\ PPGA and PROFIAP / Federal University of Rondônia, Brazil.
}

Received: August 19, 2020

doi:10.5430/ijba.v11n6p37
Accepted: October 7, 2020

Online Published: October 19, 2020

URL: https://doi.org/10.5430/ijba.v11n6p37

\begin{abstract}
The uncontrolled use of fire has resulted in innumerable occurrences of forest fires in the Western Amazon, causing damage to the environment and society, verifying its association with the effects of corruption, since it deals with the selfish behaviors of some involved actors, aiming the well-being of a minority. This study is a case study that focuses on forest fires and their relationship with corrupt practices and Theory U. It brings as its objective general study of the relationship of corruption to forest fires in the Western Amazon; and have as specific objectives to raise the causal relationship of corruption in face of the denial of Theory $U$ (1), to characterize the factors that involve the questions of the fires in the Western Amazon (2), and to offer efficient subsidies to impact the fires considering the attitudinal convergence of the Amazon (3). As a result, there is a denial of Theory $U$ in the face of the selfish conduct of individuals who cause forest fires, since they are limited to the imprisonment of satisfaction of isolated wills, without seeking to emerge a future with greater social inclusion. The subsidies pointed out in this study allow us to verify the need for effectiveness in the inspection and control actions regarding forest fires by public entities related to the environment. It is up to civil society since everyone is harmed in this process, to self-organize and demand more effective measures from environmental managers.
\end{abstract}

Keywords: Amazon, socioenvironmental management, rainforest fires

\section{Introduction}

The Theory $\mathrm{U}$ consists of methods and tools that may be employed by thousands of decision makers to face urgent systemic challenges, with oftentimes very meaningful results, as pointed out by Scharmer (2020). These actions provide changes in the social reality, going from the transformation of the ego's conscience system to the conscience of an ecosystem. That is, seeking collective well-being, as already observed by Scharmer (2020). However, there are situations in which this theory is denied, as an example, forest fires in the west of Amazonia in Brazil have become more of a problem by being associated with the underlying structural corruption which is characteristic of morally degraded countries. The selfish conduct of local actors cannot be hidden; they seek to satisfy the interests of a minority that is not committed to sustainable projects and is invasive enough in the region to mobilize under very influential leaders.

To Friede (2020), the Amazon Forest is one of the biggest tropical forests of the world and directly contributes to the planet's climatic balance. Therefore, the destruction of this biome through the use of fires may lead to impacts international-wide, such as climate change and a substantial loss of biodiversity and resources that comprehends the whole world. Although the discussion about fire occurrences in the Amazonian region is debated in scientific literature, the cause relation between these practices and corruption has not been addressed the way it was here, taking the denial of Theory $U$ as the basis for its investigative task. The end goal is to point out the subsidies that promote effective surveillance and control actions. Although this is the responsibility of public servants, enforcing it 
requires the engagement of local residents, who are the true recipients of the free environmental benefits offered by the dense forest. This paper follows its introduction stating the problem by a theoretical and conceptual review, together with its methodology and then the results that are relevant to its objectives. After the concluding section is a list of references to the works that supported the research findings.

\subsection{Research Problem and Objectives}

The research problem centers on the complex culture of the residents who repeatedly start fires in order to expand the arable space available. This scenario steadily worsens as the offenders reveal their unbridled hunger for starting forest fires, leading to severe losses to the public power of surveillance, such as the deployment of methods for limiting disaster that drain the government's treasury. These fires also ruin the country's image among the international community, which sees the state's impotence as a failure of governability. They harm both the ecosystem and the health of the human population, now made victim of the ensuing disruption. However, the fires make it clear that corruption is the first and foremost cause of this harm to humanity, due to its political-ideological aspects, the vested interests in the exploitation of forest goods, and the anti-ethical abuses from offenders who believe they can act with impunity.

For the purpose of solving this problem, the following enquiry should be addressed first: how do corruption practices relate to forest fires in western Amazonia? To answer it, the paper's general objective is to study the current relationship between corruption and the forest fires in the region. It sets specific objectives for the results of (1) surveying the causal relationships of the corruption that defies Theory $U$, (2) describing the factors involved in the issue of fires in western Amazonia. It proposes subsidies that would impact on the forests, seeing a positive response in the converging attitudes of the Amazonian people

\section{Theoretical Foundation}

The occurrence of forest fires on the western side of the Amazon rainforest have begun to increase, causing much socioenvironmental trouble in the country, as well as political, ideological and economic hazards. The concepts related to the effects of corruption may be found in the denial of Theory $\mathrm{U}$, since this theoretical source is supposed not to offer a subsidiary way of adjusting the attitude of stakeholders.

\subsection{Conceptual Aspects of Corruption and Theory $U$}

The conceptual aspects of the motivating factors of forest fires in Amazonia set corruption in the background; at the same time, the concepts of Theory $\mathrm{U}$ are brought out so as to justify studies on the causality behind this ongoing destruction. The unscrupulous group under whose auspices the forest is laid waste will be neutralized as fast as it is revealed.

\subsubsection{Concepts of Corruption}

There are several concepts of corruption in the academic literature that meets the one focused on in the present research. Obicci (2016) defines corruption as a practice that contravenes the essence of ethics, with a view to promoting self-enrichment and personal satisfaction to the detriment of the public interest; the author refers to the perversion of conduct at the interface of relationships, in which the financial interests of the corrupt group is satisfied by the violation of norms, laws and moral standards.

Corruption generally is associated with the selfish conduct of public servants; nevertheless, Medeiros and Forte (2019) have shown that 'corrupt' describes any individual who ever performs anti-ethical deeds in the public administration, whether or not $\mathrm{s} / \mathrm{he}$ is a government official. Souza et al. (2019a) highlight corruption as the consequence of social inequality, tax evasion, slowdown in economic growth and the resulting lack of resources for investment in a country, especially regarding the education of the masses, who if left unaided must submit to the humiliating conditions that the corruptor imposes on them.

These authors take a scientific approach to the panorama of corruption; they point to nepotism or the abuse of power when the family of a corrupt person takes public office; clientelism, or the exchanging of favors between the corrupt and those in society concerned in the matter, and patrimonialism, which blurs the lines between the public good and the private goods of the corrupt.

A phenomenon is built by the criminalization of such practices or by the rejection of these occurrences, which count on the citizen's courage to oppose any system that tolerates them. Yet, without effective jurisdictional control as well, it is impossible to fight the corrupt people who are often installed in the most diverse spheres of power, or enjoying protection notwithstanding their heinous actions. 


\subsubsection{Concepts Related to Theory U}

One of the definitions of Theory $\mathrm{U}$ is offered in Tinti (2014). For him, it is a set of conceptual tools and practices that can validly help managers to cope with mechanisms that lead to innovation; it includes learning processes as well as personal and collective change processes. Scharmer (2019), author of the theory, explains that a key resource for profound change and social innovation is the connection of three conditions in an inseparable whole, namely, an open mind, open heart and open will, as shown in Figure 1 and Table 1 below.

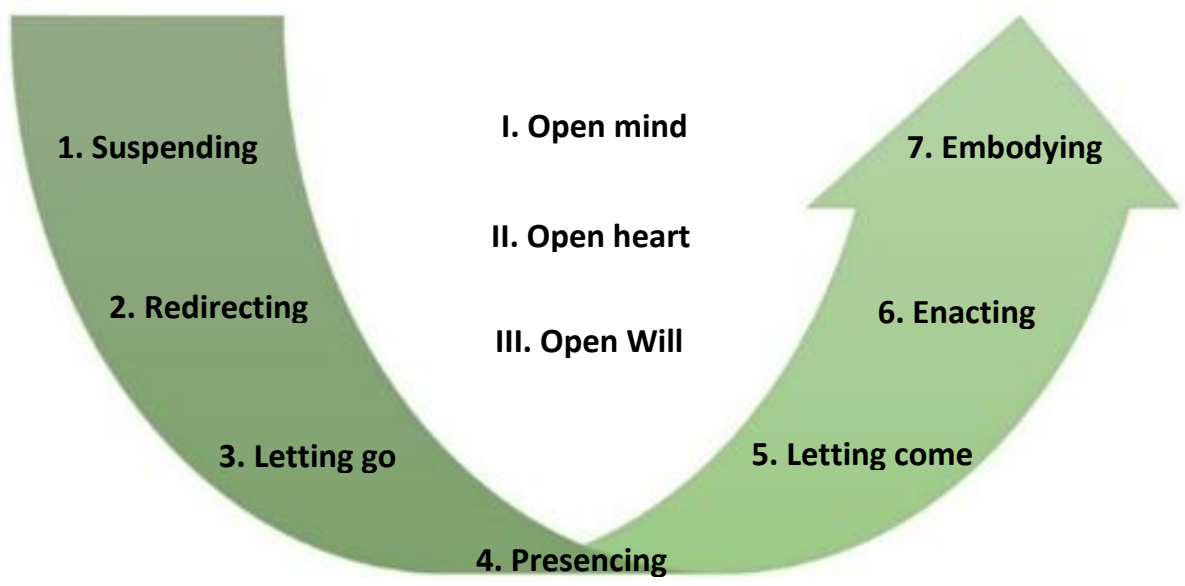

Figure 1. Theory U Diagram

Table 1. Specification of the elements of Theory U

\begin{tabular}{ll}
\hline Elements & Description \\
\hline Suspending & $\begin{array}{l}\text { To suspend past actions, to observe the world in which one is inserted, and to listen to } \\
\text { what emerges from the collective, seeking to contribute with the whole. }\end{array}$ \\
\hline Redirecting & $\begin{array}{l}\text { To redirect actions to contribute to changes in society, observing one's surroundings, } \\
\text { observing and questioning what goes on out of sight. }\end{array}$ \\
\hline Letting go & $\begin{array}{l}\text { To let go of past standards that admitted inadequate management models, and to project } \\
\text { the future by creative and innovative actions. }\end{array}$ \\
\hline Presencing & $\begin{array}{l}\text { To connect to the source, thus promoting reflection, allowing the future to emerge as a } \\
\text { whole in an individualized context, but in a general and not individualized context. }\end{array}$ \\
\hline Letting come & $\begin{array}{l}\text { To find a place for people, opportunities and resources which will contribute to positive } \\
\text { change and make way for innovative and shared management. }\end{array}$ \\
\hline Enacting & $\begin{array}{l}\text { After taking the above steps, to enact the law through the enforcement of practices, aiming } \\
\text { at transformation from the inner vision to outer action. }\end{array}$ \\
\hline Embodying & $\begin{array}{l}\text { To embody the new, whilst committing to the future that emerges from the new practices, } \\
\text { seeking innovation through constant learning. }\end{array}$ \\
\hline Open mind & $\begin{array}{l}\text { To read the world, learning by referring to others and trying to reflect on their questions } \\
\text { and proposals; }\end{array}$ \\
\hline Open heart & $\begin{array}{l}\text { To connect with individuals, not only by listening to their demands, but also by being } \\
\text { empathic towards them, so as to give meaning to their needs. }\end{array}$ \\
\hline Open will & $\begin{array}{l}\text { To feel willing to act, upon opening one's heart and mind, and aware of all the possibilities } \\
\text { that may emerge from this interaction. }\end{array}$ \\
\hline
\end{tabular}


The theoretical reading presented here may be reflected in behavioral change by the Amazonian people as social actors in fire drills, for it enables individuals and groups to understand better how harmful these practices are. Furthermore, they learn that, in resisting the actors who benefit from their indifference, whether by tolerance or by fraudulent adherence, they perpetuate the harm to public goods. Thus, if they adhered to the positive purpose of Theory U, they would avoid these impediments to collective well-being that there are bound to be in the environmental services of the Amazon rainforest. Research by Graça (2019) skillfully deals with the denial of Theory U; it gathers evidence of some people's selfish and anti-ethical practices. The reversal of Theory U is shown in Figure 2 and in Table 2.

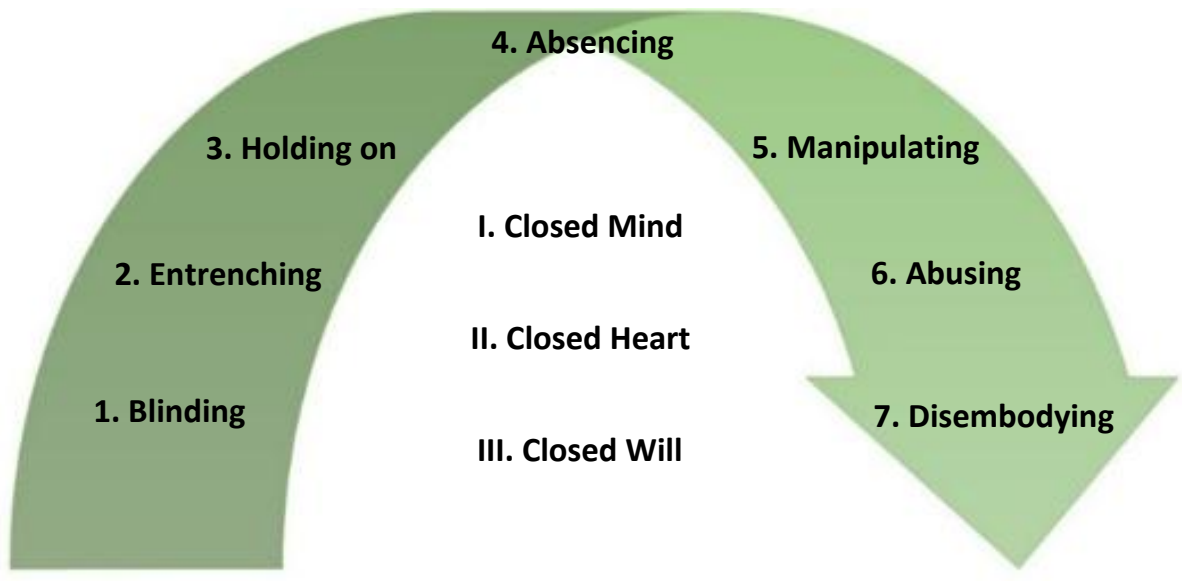

Figure 2. Diagram of the denial of Theory $U$

Table 2. Specifications of the elements in the denial of Theory U

\begin{tabular}{ll}
\hline Elements & Description \\
\hline Blinding & $\begin{array}{l}\text { To keep past patterns without seeking to break them, sticking to a truth that prevents the } \\
\text { perception of the world. }\end{array}$ \\
\hline Entrenching & $\begin{array}{l}\text { To prevent changes that would improve the process, sustaining practices focused on } \\
\text { personal satisfaction instead of seeking to meet the needs that emanate from the collective. }\end{array}$ \\
\hline Holding on & $\begin{array}{l}\text { To insist on living in an uninventive world, letting individualistic practices prevail and } \\
\text { harming social well-being, together with the well-being of ecosystems. }\end{array}$ \\
\hline Absencing & $\begin{array}{l}\text { To be stuck in old patterns, moving away from the pursuit of critical reflection on decisions } \\
\text { made which sustains a model of individualized conduct. }\end{array}$ \\
\hline Manipulating & $\begin{array}{l}\text { To disseminate an ideology that values the maintenance of old standards, meaning that } \\
\text { society does not believe in positive changes brought by the emerging future. }\end{array}$ \\
\hline Abusing & $\begin{array}{l}\text { To conserve an old-fashioned vision based on old paradigms, preventing the future from } \\
\text { changing through the possibilities created by insight. }\end{array}$ \\
\hline Disembodying & $\begin{array}{l}\text { To eliminate any chance of innovation, geared by will to get rid of transformations that } \\
\text { might work for the collective well-being by means of constant learning. }\end{array}$ \\
\hline Closed mind & $\begin{array}{l}\text { To obstruct the possibility of analyzing and interpreting the world, blocking the expression } \\
\text { of other individuals' questions and proposals. }\end{array}$ \\
\hline Closed heart & $\begin{array}{l}\text { Failing to connect with other people, not seeking to give meaning to the needs in oneself } \\
\text { that tend towards collectivity. }\end{array}$ \\
\hline Closed will & $\begin{array}{l}\text { As neither a mind nor a heart is open, there is even less will to act in favor of social } \\
\text { improvement in general. }\end{array}$ \\
\hline
\end{tabular}


Arendhardt et al. (2018) highlight Theory $U$ as a way of promoting social transformation, through individual actions that are designed for the community. These mark phases of full awareness among the actors involved in the process, with significant capacity to put pressure on the state's power to help reverse old habits. Through affirmative policies, leaders empower the social actors to assume a new stance from enforcing the legal norms, once they have taken social, environmental, and economic responsibility for a sustainable vision.

\subsection{The Concept of Fires in Amazonia and Its External Implications}

The permission to set light to vegetation is not unconditional; environmental agencies used to give authorization with rules for its control, preventing the rupture of pre-established objectives or the risk of a conflagration, as indicated in Brazil (2012). This would entail the uncontrolled burning of any form of vegetation; but Souza et al. (2019b) point out that in the Amazon such occurrences have become part of the residents' culture, aggravated by the need to provide new areas for agriculture and ranching; they have opened the door to significant increases in fires that are proportional to the increase of economic activity in the region.

Penha (2019) highlights the reduction in the amount of forest biomass and carbon stocks, and the consequent increase in greenhouse gas emissions. Leandro and Laudeano (2018), for their part, look at the socioeconomic impact of forest fires, including disturbances to the population and the landscape, the beauty of the environment and areas of recreation and the local tourist activities. Fires also attack human health because respiratory diseases, especially during the present COVID-19 pandemic, bring large contingents of patients to hospital when smoke aggravates the difficulty of breathing.

In any economic activity, the causative actor can bring costs or benefits to third parties. These are the main externalities addressed in Silva et al. (2016). Environmental externalities are also considered by Kruger and Petri (2018) as key concepts for sustainability; these authors affirm that external features can be negative when their impact is prolonged, potentially affecting people's well-being in particular when they live in remote or inaccessible places.

Environmental externalities have been discussed internationally in the literature offered by Rayamajhee and Joshi (2018), as well as by Bellver-Domingo, Hernández-Sancho, and Molinos-Senante (2016). In the same way, empirical studies have found practices carried out by individuals that directly affect the environment, through measures incompatible with those desired by stakeholders and generating undesired consequences, as explained by Rayamajhee and Joshi (2018). This is why Silva et al. (2016) reinforce everyone's responsibility in exploiting natural resources, since nature is interconnected with society, and the actions of any agent can have an external socio-environmental impact. These arguments best draw out the concepts of socioeconomic and environmental relations that are outlined in the present paper.

\subsection{Concepts of the Attitude of Convergence of Amazonian People}

Most public policies implemented in the Amazon disregard the way of life and sociocultural knowledge of the people who live there; they ignore the concepts underlying the residents' social relations with the natural world around them, according to Lira and Chaves (2016). In this context, Rolim (2018) stresses the need to develop an innovative social vision, based on ethical concerns. It should include subjects hitherto invisible, and an agenda to guarantee their rights through the full exercise of citizenship while finding ways to lift them out of their passivity. In the view of Santos et al. (2018), these are conceptual challenges posed by the particular nature of areas where individuals have little access to information about the quality of life. They explain the individuals' low awareness of their own situation, while accustoming them to a predatory relationship with natural resources.

Valdiones and Thuault (2017) also address the trustworthiness of environmental information in the Amazon, which has a negative impact on the governance of natural resources because it impedes the control bodies appointed to inspect action that impinges on the environment. They reveal objectionable practices, such as illegal deforestation and attitudes that condemn the Amazonian stakeholders to economic underdevelopment, while the region continues to be at the mercy of inadequate public services, especially in the rural areas. Infrastructure is absolutely undeveloped and the communities which still live in the forest have only inefficient education, health care, transport, security and other basics to depend on for their concept of the situation and their attitude to the world around them.

\section{Methodology}

This study followed the guidelines of Creswell (2014) for qualitatively approaching a descriptive task. It took the form of a case study of forest fires in the Amazon, the effects of corruption and the denial of Theory U. It was based on scientific publications that helped to interpret the facts and to develop a response to them. 


\subsection{Case Study Method}

The method is the key to conducting research; so much so that Saunders et al. (2016) define this term as the usual procedures and techniques for obtaining, analyzing, and processing data, including their ethical aspects. The method used for the present research was the Case Study, defined by Merriam and Tisdell (2016) as an investigative practice in which a detailed description is carried out, including the analysis of a delimited system. For Yin (2014), this method of empirical study investigates a contemporary phenomenon in a factual context, especially when the boundaries between phenomenon and context do not require disclosure. The exploration of bibliographic collections focused on the topic identified above.

\subsection{Adopted Procedures}

The detail of the methodological procedures adopted for the present case study is shown in Figure 3, followed by the specific Table 3.

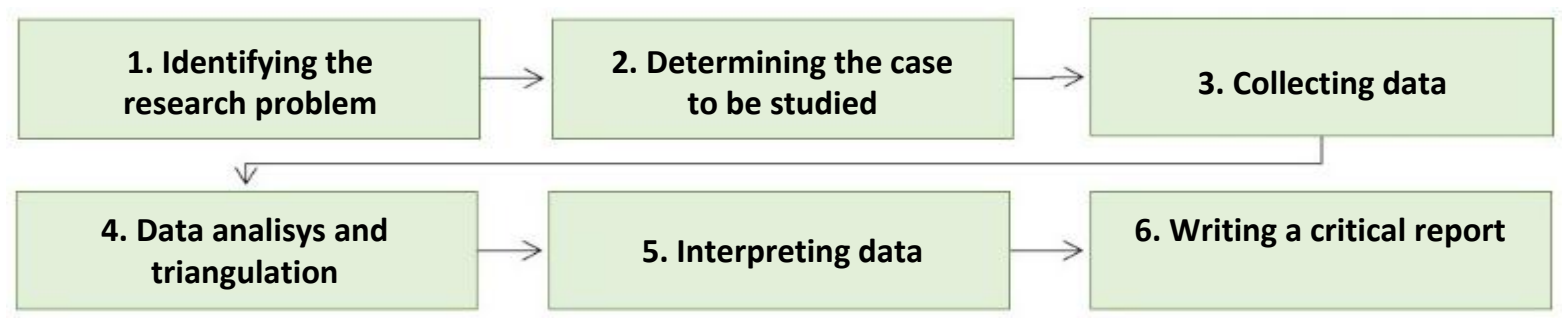

Figure 3. Phases of execution of the Case Study

Table 3. Specification of the elements of Theory U

\begin{tabular}{ll}
\hline Elements & Description \\
\hline Research problem identification & $\begin{array}{l}\text { Determining the problem, in order to choose the qualitative method that } \\
\text { best contributes to the in-depth analysis and understanding of the } \\
\text { phenomena. }\end{array}$ \\
\hline $\begin{array}{l}\text { Determination of the case to be } \\
\text { studied }\end{array}$ & $\begin{array}{l}\text { The present case concerns forest fires in the Amazon, which are evaluated } \\
\text { in terms of corrupt practices and the denial of Theory U. }\end{array}$ \\
\hline Data collect & Capturing the primary sources, mainly documents and archival records. \\
\hline Data analysis and triangulation & $\begin{array}{l}\text { Considering the collected data as sources of information, analyzing them } \\
\text { and describing the details of the case in order to understand the problem. }\end{array}$ \\
\hline Interpretation of Data & $\begin{array}{l}\text { Final interpretation of the research, based on the collection and } \\
\text { triangulation of related data to define the meaning of the case under study. }\end{array}$ \\
\hline Critical Report Writing & $\begin{array}{l}\text { Presenting the interpretation in a critical report, comprising the lessons } \\
\text { learned from the case. }\end{array}$ \\
\hline
\end{tabular}

\section{Study of Socio-Environmental Management, the Denial of Theory $U$ and Fires in the Amazon Region}

This topic includes a description of the causes of forest fires in the Amazon, the effects of corruption in these occurrences, and the denial of Theory U. It outlines the factors involved in these matters, indicates efficient subsidies that would have the effect of preventing these fires, and considers the convergence in attitude of the Amazonian people who benefit from forest services. 


\subsection{Survey of the Causal Relationship}

The National Institute for Space Research (INPE, 2019), from January 1 to October 9, 2019, recorded 68,728 fire spots in the Amazon biome. This index corresponds to an increase of $39 \%$ over the number in the same period of the previous year. This alert was serious, signifying an increase of 36.3\% in the statistics of fires over the period indicated above, compared with the Cerrado, which showed a 33\% increase, and the Caatinga showing 15.9\%. These are striking percentages in regard to the commitment of residents to their habitat. This environmental loss calls for a study of the events around it and for discussion by social scientists. This would allow society to understand the context from the perspective of the consequences of corruption. The heat spots registered up to October 10, 2019 by the National Institute for Space Research (INPE, 2019) are shown in Figure 4.

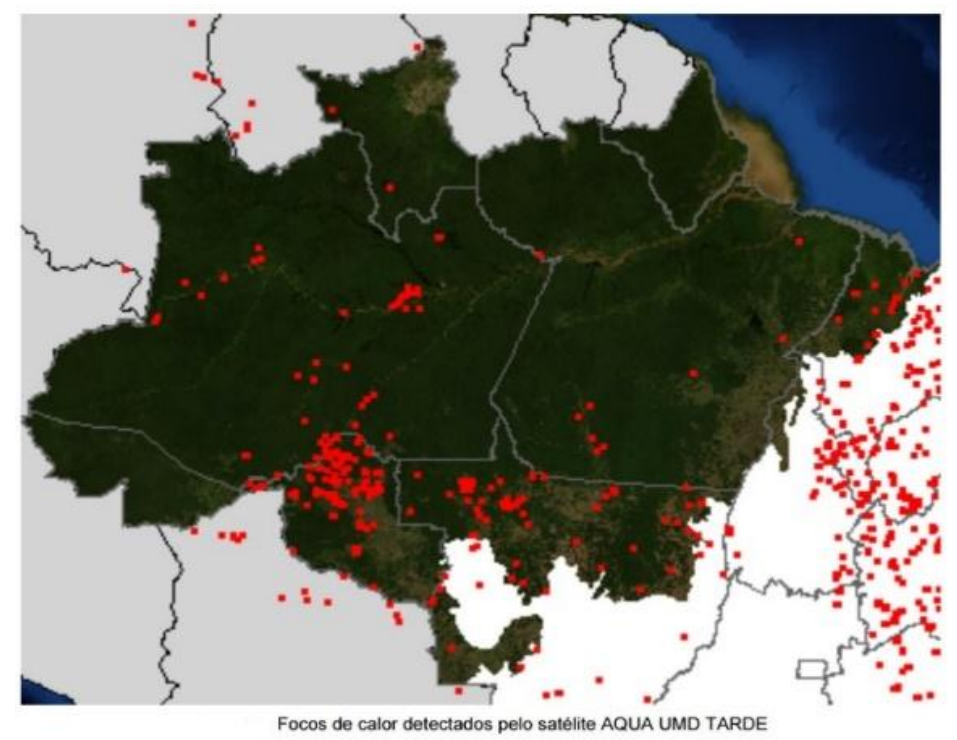

Figure 4. Heat spots in the Amazon, according to INPE on October 10, 2019

There is no denying that forest fires in the Amazon are linked to the corrupt conduct of those who should be benefiting from a healthy environment. They occur without government control, and feed on the silence of those who should report them. However, despite civil demonstrations trying to end these degrading practices, studies in Soares (2017) point to the usual weakening of the supervisory public power. But it is common knowledge that local leaders covertly command most of the incidents that can result in social conflict, when whistleblowers are murdered and those who speak up face retribution. Fear of such things prevents residents from initiating a definitive solution, thus indicating the clear social control under which they live.

\subsubsection{Corruption Sustains Forest Fires by Forcing Denial of Theory U}

This research confirmed the predominance of a selfish attitude in incendiary individuals, corroborating studies by Obicci (2016) and Medeiros and Forte (2019), who's reading focuses on such attitudes, which are associated with corruption. Most corrupt people seek large profits from their economic activities, with no respect for the environment or the current legal rules. With corruption working as their basic engine, they are involved in cases of fire in the investigative locus; where the bourgeois media are present; they are manipulated by the desires of powerful figures that control civil society. The theoretical writings of Graça (2019) help to interpret such events; he wants to highlights the basic picture of prisoners in an isolated world-view, fed by the fanatical urge to make quick and easy gains. This negative image suggests that communication between environmental managers and the actors who burn down the forest is always unilateral and linear, without transparency.

The intention to cater for the interests of a minority is clear and manifest, since it is verified by the occurrences reported in the current emergency. The outcry went from local to international level, but it is always carried by sensationalists and media news reporters. However, the strength of the state's control in its three governmental spheres has been relentless, with arrests, the blockade of predatory acts, police actions to identify criminal groups and their hidden leaders. 
A whole apparatus was deployed against offenders in this serious increase of forest fires; the government had to spend extraordinary amounts on re-locating specialized garrisons to fight fires, on civil and police investigations of offenders, and on vigorous clashes with the sort of powerful and influential politicians who intervene in a particular interest. However, the support of criminals by certain local leaders, either in an attempt to avoid being recognized, or to prevent the prosecution of the fire-raisers in the Amazon basin, has not been successful.

\subsubsection{Fighting Forest Fires and the Reaction to the Denial of Theory U}

To combat the corrupt actions related to forest fires, it is interesting to look at the fundamental elements in Theory $\mathrm{U}$ and thereby obtain valid and efficient subsidies to reduce these practices. Such an approach makes it possible to assist the actors involved in this process, including the environmental managers as well as the inhabitants of the Amazonian communities. It is done by providing guidance for those in a situation of this kind through a significant learning process, which lets them make a personal and collective change in their perspective.

The effects will come from the stakeholders, who now appear with an ethical stance, characterized by respect for principles and clear values in society. It leads to social and environmental well-being, in the manner shown in Figure 5 and Table 4, as follows.

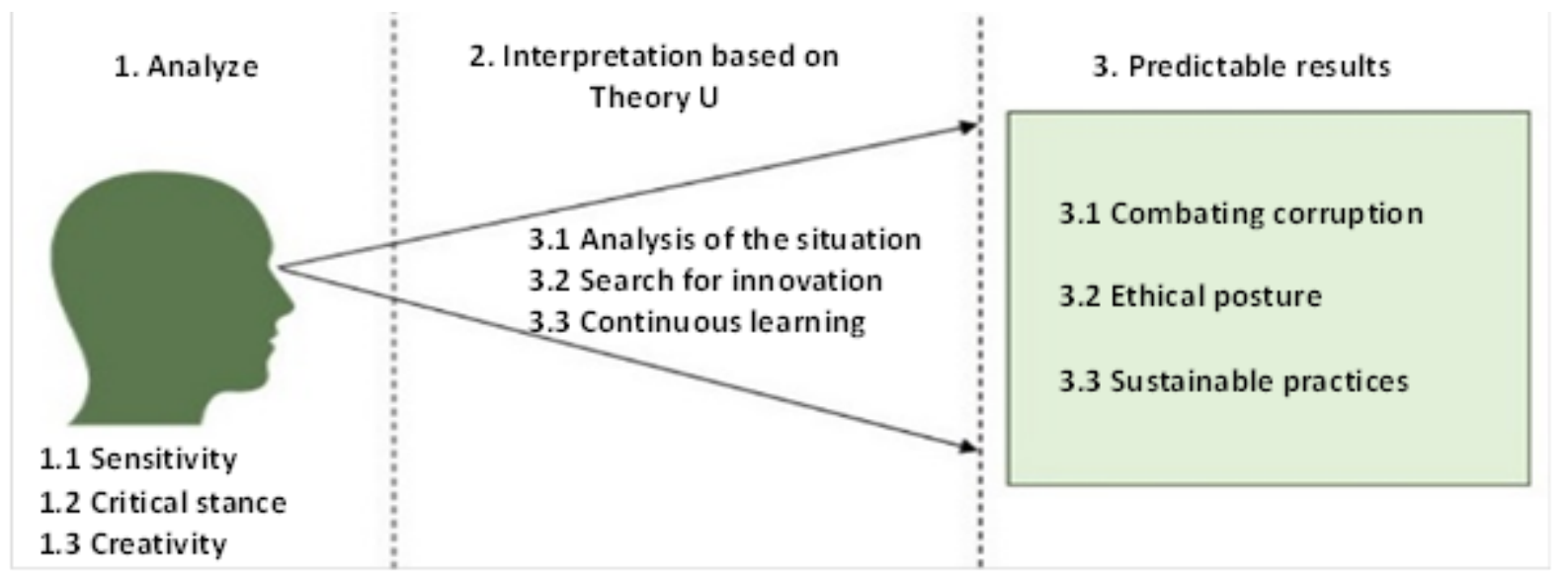

Figure 5. Evaluation diagram by environmental managers in terms of Theory $\mathrm{U}$

Table 4. Specifications of the evaluation by environmental managers in terms of Theory $\mathrm{U}$

\begin{tabular}{|c|c|}
\hline Elements & Description \\
\hline \multirow{3}{*}{ 1. Analysis } & $\begin{array}{l}\text { 1.1 Sensitivity to the perception of social, environmental, and economic demands in the current } \\
\text { context. }\end{array}$ \\
\hline & 1.2 Critical posture in evaluating the current situation, thus making more appropriate decisions. \\
\hline & 1.3 Creativity in developing actions that supply emerging needs. \\
\hline \multirow{3}{*}{$\begin{array}{l}\text { 2. Interpretation } \\
\text { based on Theory U }\end{array}$} & $\begin{array}{l}\text { 2.1 Analysis of the socio-environmental situation, giving up old paradigms that generate only } \\
\text { dissatisfaction for the population. }\end{array}$ \\
\hline & $\begin{array}{l}\text { 2.2 Search for actions emerging from the collective, in order to contribute to positive changes } \\
\text { for society. }\end{array}$ \\
\hline & $\begin{array}{l}2.3 \text { Constant search for new learning in order to gradually transform the current scenario for the } \\
\text { better. }\end{array}$ \\
\hline \multirow{3}{*}{ 3. Expected results } & $\begin{array}{l}\text { 3.1 Implementing actions that aim at collective well-being and preventing practices that aim only } \\
\text { at the satisfaction of a minority. }\end{array}$ \\
\hline & 3.2 Ethical conduct, assuming a posture that respects society's norms, conduct and values. \\
\hline & $\begin{array}{l}\text { 3.3 Guarantee of sustainable development, with the objective of ensuring the quality of life of the } \\
\text { current and future generation. }\end{array}$ \\
\hline
\end{tabular}


In fact, society suffers from enduring traditional habits that prevent it from reviewing its old paradigms; this aspect serves the interests of the minority in control, to the detriment of collective benefits, through manipulation, which encompasses everything from unreasonable promises to threatening those who dare to react. However, it remains clear that the practices related to forest fires are not consistent with guidance from Theory U. Individuals and their communities are indifferent to the harmful effects of fire on forest preservation, despite their perception of the situation in their surroundings, as shown in Figure 6 and Table 5 below.

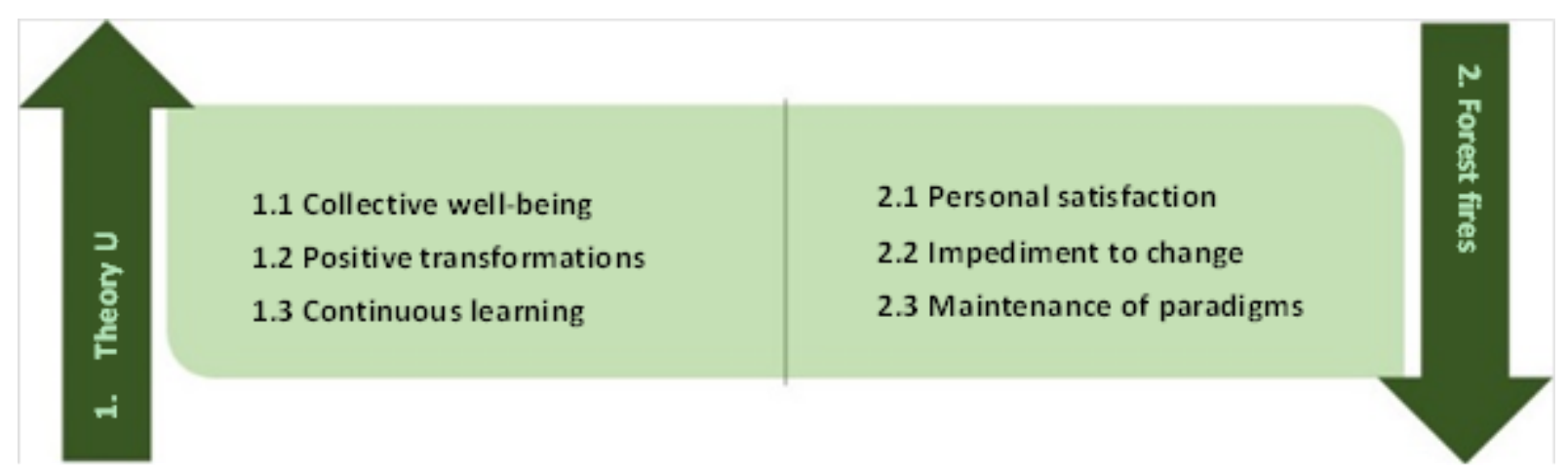

Figure 6. Diagram showing the contradictions between forest fires and Theory $\mathrm{U}$ as concepts

Table 5. Specifications of the contrary conceptions between forest fires and Theory $\mathrm{U}$

\begin{tabular}{ll}
\hline Elements & Description \\
\hline 1. Theory $\mathbf{U}$ & $\begin{array}{l}\text { 1.1 Search for solutions to the current problems that emerge from the collective, within a } \\
\text { general and not individualized context. }\end{array}$ \\
& $\begin{array}{l}1.2 \text { Innovations through profound changes in actions, that affect the whole of society. } \\
1.3 \text { Constant search for new actions through learning, seeking more and more } \\
\text { improvements for the collective. }\end{array}$ \\
\hline \multirow{2}{\text{2.Forestfires}}{$\begin{array}{l}\text { 2.1 Development of practices that aim only at individualized well-being, with little respect } \\
\text { for society and the environment. } \\
\text { 2.2 Imprisonment in old habits, insisting on living in a world where selfish and } \\
\text { individualistic practices prevail. } \\
\text { 2.3 Maintaining an antiquated view with a focus on the old paradigms, preventing } \\
\text { transformation of the future. }\end{array}$}
\end{tabular}

\subsection{Characterization of the Factors That Involve Fire Issues in the Western Amazon}

This paper deals with the factors that contribute to the negative impacts on society and the environment as represented by the forest fires on the western side of the region. The techniques used to discourage the practice of using fire among traditional rural producers have only recently succeeded and the frequency of fires in the country continues to be high. Sodré et al. (2018) point out that the reluctance to reveal occurrences is caused by economic factors, associated with cheap and rapid actions to create clean and fertilized soil.

It is also worth mentioning that forest fires are linked to deforestation; thus, Silva et al. (2019) explain that even the Conservation Units are destroyed, because they are the target of land disputes; in these units fires are lit and roads ae opened up in defiance of institutional control. This must be the result of corruption because the offenders are aware of their actions. Offenders seek to justify their claim that it is hard to tell controlled burning apart from forest fires. But for Fagundes (2019), discriminating between excessive or abusive burning and necessary controlled burning must conform to environmental standards. This implies a normative awareness that excludes conceptual conflict because such conflict contributes to the bending of laws on the use of fire, while opening a gap for the corrupt practice of starting forest fires in the region. 
The lack of effective inspection and control measures in combating forest fires is another aggravating factor. Some suspect that there is a possible game of interest between the inspectors and the main guilty parties. But it is the lack of transparency in the investigations that raises doubts about accountability, given the specific evidence that those accused were involved. This finding is supported by Medeiros and Forte (2019), who explain that the corrupt acts between the public officials and the accused persons testify to the noncompliance with the principles of the government. The limited awareness of negative dealings among those involved can be verified; so it is left to the environmental managers to enlighten the public and give guidance about new procedures that should replace their traditional readiness to burn vegetation. With regard to prevention policies and forest fire control, Fonseca-Morello et al. (2017) list the root causes of the perpetuation of firing and, consequently, maintain a desirable level of fire risk, as shown in Figure 7 and detailed in Table 6.

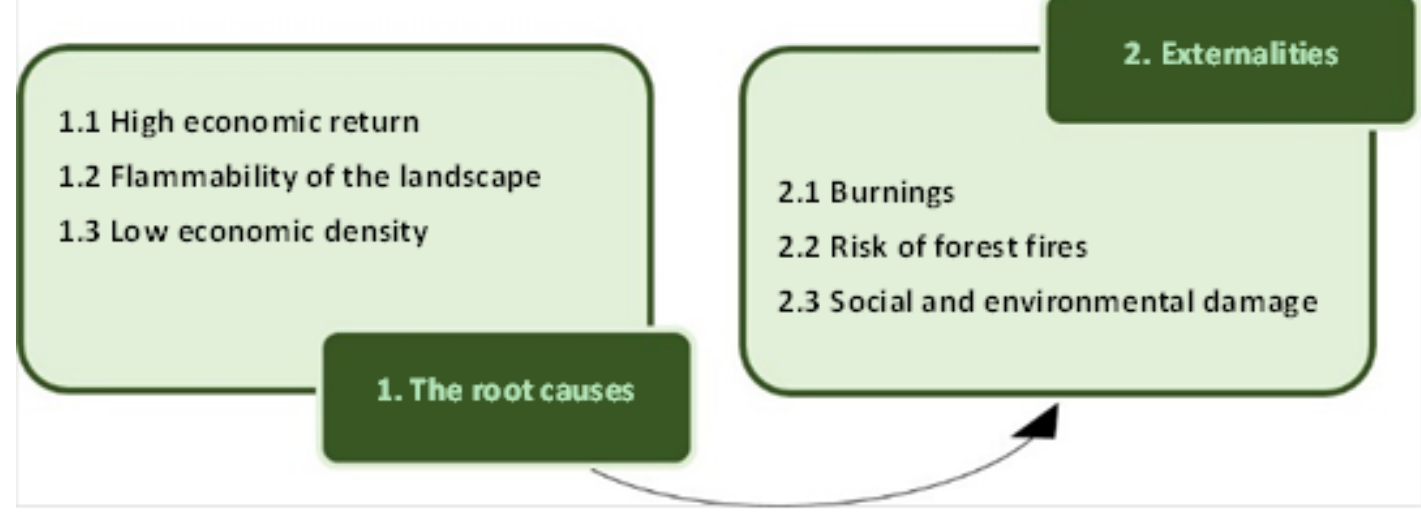

Figure 7. Diagram of elements related to forest fires

Table 6. Details of the elements related to forest fires

\begin{tabular}{ll}
\hline Elements & Description \\
\hline 1. The root causes & $\begin{array}{l}\text { 1.1 The effectiveness of fire for removing residues from converting land cover is that it keeps } \\
\text { down expense in its preparation, unlike manual or mechanized preparation. } \\
\text { forest and with high precipitation rates. } \\
\text { 1.3 Few inhabitants in this region, making a fire seem like an isolated event; people are too } \\
\text { poor to install fire-prevention equipment. }\end{array}$ \\
\hline $\begin{array}{l}\text { 2.1 Higher numbers of fires in the region, guided only by irrational calculations of individual } \\
\text { cost-benefit. }\end{array}$ \\
$\begin{array}{l}\text { 2.2 Inability of the government to directly measure the level of forest fire risk; it depends on } \\
\text { many decentralized estimates, further increasing this risks. } \\
\text { 2.2 Damage to the environment, impacting on fauna and flora, as well as damaging the } \\
\text { population's quality of life, by the increase in cases related to respiratory diseases. }\end{array}$ \\
\hline
\end{tabular}

From the above external evidence, one can observe why Kruger and Petri (2018) and Silva et al. (2016) recommend interfering to secure the well-being of the local and regional population, as well as in geographically distant scenarios; it is done to affect the quality of life of future generations, while safeguarding the reserves of natural resources for generations. It is also worth noting the orientation given by Theiss et al. (2015), that the government has a key role in finding solutions to externalities, since it can work with regulatory standards to generate activities that limit negative externalities and subsidize those that cause positive externalities, for the benefit of society in general and the environment. However, enforcement will not occur without new learning, as recommended for this task. 


\subsection{Indication of Efficient Subsidies to Combat Fires, Considering the Convergence in Attitude of the Amazonian People}

The phenomenon of uncontrolled forest fires in the Amazon is permeated by underlying forces in the government's default; institutional fragility must be considered, low effectiveness in economic and environmental public policies, and the diffusion of government interests. These are aspects that combine with each other to make it unfeasible to block the practice of burning. Since there is no strict inspection and control, the feeling of powerlessness among citizens makes them passive before the aggressiveness of this phenomenon which affects their socio-environmental well-being. This argument is supported by Lira and Chaves (2016), who find a lack of consideration for the culture, tradition, and values of the Amazonians when the target is only the natural resources existing in the region. Moreover, when community members decide to express their dissatisfaction about the harm caused by forest fires, these individuals start to suffer retaliation from the causative actors, and this makes any resistance unfeasible. Furthermore, it is necessary to highlight the challenges faced uniquely by the Amazonians. They are sometimes treated as invisible citizens, due to their difficulties in accessing information, education, and security Their plight is corroborated by the Social Progress Index in the Brazilian Amazon (IPS Amazônia) in Santos et al. (2018), where their average index of access to information and communication was identified as no more than $53.35 \%$ to $54.24 \%$ between the years 2014 and 2018. No other region had so low a result, although the national average in the same period was only $66.67 \%$. These statistics suggest why the residents do not resist the saboteurs but allow them to start more forest fires, clearly contravening Theory $\mathrm{U}$ in doing so. These logical arguments are shown in Figure 8 and the details in Chart 7 below.

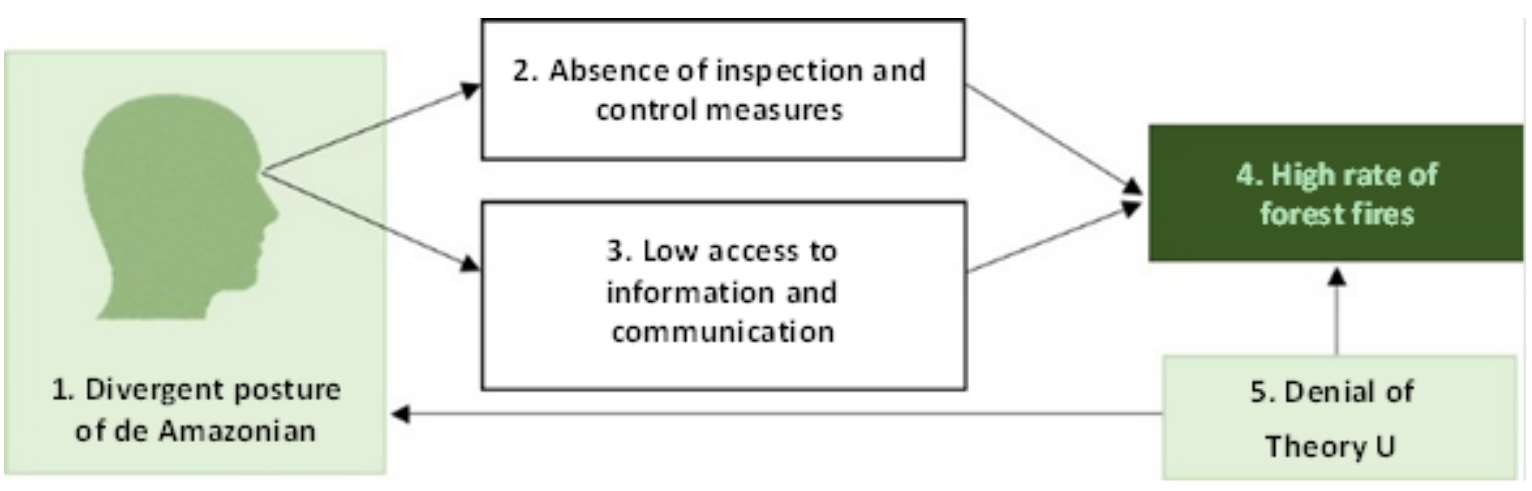

Figure 8. Diagram of the Amazonian posture in the face of forest fires

Table 7. Specifications of the Amazonians' posture in the face of forest fires

\begin{tabular}{|c|c|}
\hline Element & Description \\
\hline \multirow{3}{*}{$\begin{array}{l}\text { 1. Amazonias's divergent } \\
\text { posture }\end{array}$} & $\begin{array}{l}\text { 1.1 Amazonians analyze the world in which they live and end up assuming an } \\
\text { incongruous posture. }\end{array}$ \\
\hline & $\begin{array}{l}\text { 1.2 They feel powerless and lack the ability to organize in the fight against those who } \\
\text { light forest fires in the region. }\end{array}$ \\
\hline & $\begin{array}{l}1.3 \text { They coexist with these corrupt practices, even when harm is done to individuals and } \\
\text { the ecosystem. }\end{array}$ \\
\hline \multirow{3}{*}{$\begin{array}{l}\text { 2. Absence of inspection } \\
\text { and control measures }\end{array}$} & $\begin{array}{l}\text { 2.1 The combined Interests of those involved intensify the situation so that individuals } \\
\text { start to encourage the maintenance of the practices. }\end{array}$ \\
\hline & 2.2 The government authorities fail to act rigorously by to combat such practices. \\
\hline & $\begin{array}{l}2.2 \text { The practices are supporting in a corrupt way, aimed at satisfying only the greed of a } \\
\text { few individuals. }\end{array}$ \\
\hline $\begin{array}{l}\text { 3. Low access to } \\
\text { information and } \\
\text { communication }\end{array}$ & $\begin{array}{l}\text { 3.1 It is hard to get enough information to know what is happening. } \\
\text { 3.2 The information that arrives is twisted and distorted; it does not clarify the facts as } \\
\text { they occur. }\end{array}$ \\
\hline
\end{tabular}


3.3 Amazonians have too little communication with other members of civil society to access quality information.

4.1 Fires are more and more frequent due to the low inspection and control of them.

4. High rates of forest fires

4.2 The limitedly rational and autonomous actors are guided only by individual cost-benefit calculations.

4.3 Their disrespect for the environment and society in general lets the selfish conduct of some individuals damage these things

5.1 As feedback, it appears that the previous elements have a causal relationship.

5. Denial of Theory $U$

5.2 The divergent posture of the Amazonians, indirectly encouraging forest fires, contributes to the denial of Theory $\mathrm{U}$.

5.3 As a result, individuals are trapped in this situation, blocking the possibility of social transformation.

Social transformation is possible through the application of Theory U, as recommended by Graça (2019). The author advocates the breaking of a fixed mentality as the priority, in order to let transformative ideals grow. Unlocking is also essential, because it underlies the possibilities for change. These arguments by Graça can be enforced only a change in attitude that involves the mind, heart and will. These are moments in the painful process of breaking with tradition and culture; however, they make way for the $\mathrm{U}$ path, towards innovation and a propitious future that emerges moment by moment. According to Graça, these elements must also be applied to leaders, so that they decide to accept interdependence and ecological, economic, social, and spiritual/cultural connection. They must agree and be willing to change and innovate, in solving complex problems like the tradition of burning in the Amazon. Figure 9 below show the perspective from which to consider the theoretical overcoming of Amazonians and community leaders; Table 8 provides guidance in facing the temptations common to everyone in the region.

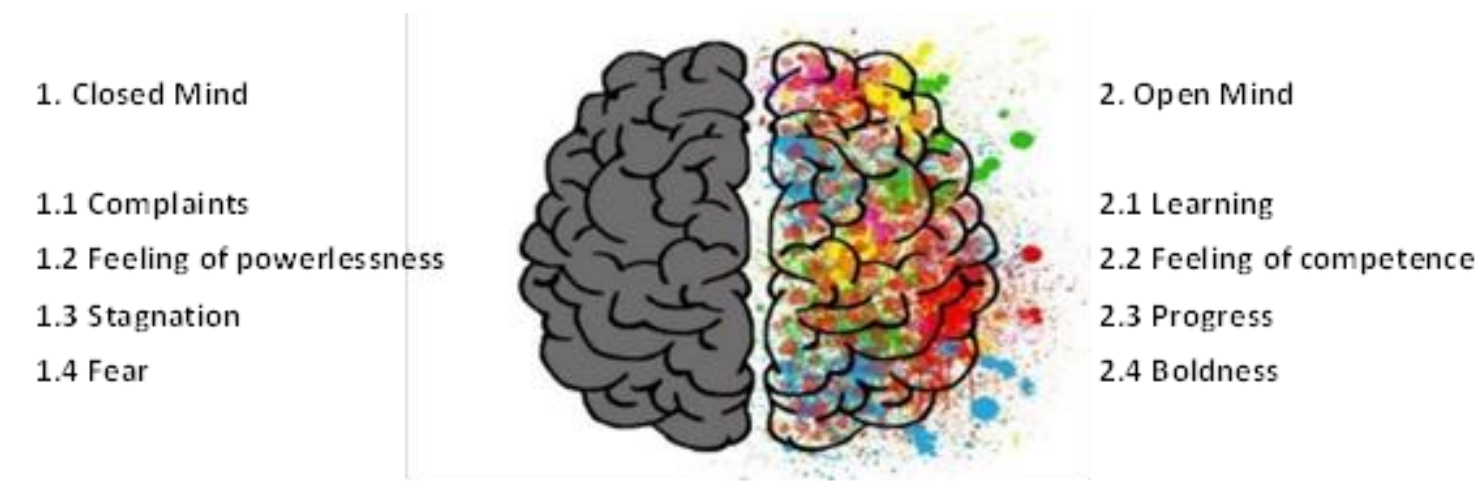

Figure 9. Breaking mental barriers

Table 8. Specifications of the elements in the breaking of mental barriers

\begin{tabular}{ll}
\hline Elements & Description \\
\hline $\begin{array}{l}\text { 1.1 Individual dissatisfaction with the scenario coupled with no search for efficient measures to } \\
\text { procure of positive change; only complaints about fires. } \\
1.2 \text { Feeling of inability to transform the context in which the individual is inserted, since } \\
\text { transformation would require awareness and the motivation to change attitude. } \\
11.3 \text { Imprisonment in a situation that brings only discomfort and dissatisfactions, leading } \\
\text { people to accept the discomfort of uncontrolled fires. } \\
\text { 1.4 Fear of expressing opinion that criticizes the situation, due to external pressures or social } \\
\text { control; it is important to strengthen morale. }\end{array}$ \\
\end{tabular}


2.1 The individual constantly seeks new learning in order to positively and incrementally transform the conditions of life.

$2.2 \mathrm{~S} /$ he feels like an active subject, able to carry out social transformation for the benefit of the community.

2. Open mind

2.3 Transformation to increasingly better conditions, with the ideal of social and environmental well-being.

2.4 Courage to face whatever situations are imposed and to demand changes for collective satisfaction, far from the malaise of burning trees in the Amazon.

Even though they result in losses to society and the environment, forest fires, as this study shows, are not yet given their due importance in political discussions on the value of the environmental benefits from forests. Indeed, Fonseca-Morello et al. (2017) emphasize the need to implement bottleneck policies by distinguishing between institutional weaknesses; these are generally imposed by socioeconomic conditions, but compensating for them must be a policy objective in turn; it will require a self-organized society's to impose effective policy actions aimed at monitoring and controlling fires.

The starting point is the change in behavior / mentality proposed in Graça (2019), to be initiated through productive dialogue, ensuring healthy communication between those involved; it will generate people's commitment and involvement in solving the collective problems of forest fires and uncontrolled fires.

\section{Conclusion}

The above analysis of the results shows clearly that corrupt practices are related to the occurrences of forest fires in the Amazon. The main motivator is associated with the interest in deforestation for economic growth, from individuals led solely by their personal interests. What should also be kept in mind is the lack of effective inspection and control of these practices in a vast forest, exposed to resident actors who are rooted in a feeling of powerlessness and fear to face what they disagree with.

In addition, when inspection and control occur, biased reactions soon make themselves heard but this selfish conduct meets with impunity in the end, bringing negative external consequences of various kinds. As a result of reversing Theory $\mathrm{U}$, the attitudes of these individuals and their leadership seem rationally limited by the individual interests of a few, consequently bringing the social and environmental damage claimed at the national and international levels. When this happens, the search for sustainable social innovation becomes necessary, and is driven by proactive continuous learning.

There is no doubt that the changes that emerge from individuals add up to collective change. They now realign economic development to environmental preservation, while optimizing agricultural activities with environmental conservation, through the rational use of the agricultural spaces available in the region, without destroying the native forest. They reflect the quality of life of the Amazonian population in the current scenario with guarantees of a successful future for re-educated and conscious communities. Thus, this study is yet another academic contribution to leaders/ managers interested in making general changes in attitude, and changes in particular in those relationships involving socio-environmental complexities in a fragile scenario. In this task, public policy makers are suggested to have a greater social concern regarding the effectiveness of their actions, seeking greater rigor in the control and inspection of fires, because it has provided international environmental externalities.

\section{References}

Arenhardt, V., Pedro Filho, F. S., Oliveira, L. R. A., Nogueira, I. C. S., \& Deliza, E. E. V. (2018). Inovação social com base na Teoria U com foco no gerenciamento dos resíduos sólidos domiciliares. São Paulo: XX Engema.

Bellver-Domingo, A., Hernández-Sancho, F., \& Molinos-Senante, M. (2016). A review of Payment for Ecosystem Services for the economic internalization of environmental externalities: A water perspective. Geoforum, 70. https://doi.org/10.1016/j.geoforum.2016.02.018

Creswell, J. W. (2014). Investigação qualitativa e projeto de pesquisa: escolhendo entre cinco abordagens. Porto Alegre: Penso.

Fagundes, G. M. (2019). Fire normativities: environmental conservation and quilombola forms of life in the Brazilian savanna. Vibrant Virtual Braz Anthr, 16. 
Fonseca-Morello, T., Ramos, R., Steil, L., Parry, L., Barlow, J., Markusson, N., \& Ferreira, A. (2017). Queimadas e Incêndios Florestais na Amazônia Brasileira: porque as políticas públicas têm efeito limitado?. Ambiente $e$ Sociedade, 20(4).

Friede, R. (2020). Floresta Amazônica: ainda um inferno verde ou agora um paraíso ameaçado?. Revista do Exército Brasileiro, 156(1).

Graça, J. L. (2019). Gestão da inovação em reciclagem de resíduos em face dos preceitos da Teoria U. Dissertação Mestrado em Administração, Universidade Federal de Rondônia, Porto Velho: PPGA/UNIR.

Instituto Nacional De Pesquisas Espaciais (INPE). (2019). Monitoramento de queimadas e incêndios. Retrieved from https://amazoniareal.com.br/nao-adianta-culpar-o-para-fumaca-em-manaus-veio-das-queimadas-no-amazonas-d iz-inpe/focos-de-calor-na-tarde-de-02-10-inpe/

Kruger, S. D., \& Petri, S. M. (2018). Avaliação da sustentabilidade da produção suinícola sob o enfoque das externalidades. Revista Universo Contábil, 14(2).

Leandro, L. P. A., \& Laudeano, L. P. M. (2018). Mapeamento e diagnóstico da ocorrência de incêndios florestais no bairro Igrejinha e entorno - Juiz de Fora (MG). Trabalho de Conclusão de Curso, Bacharel em Engenharia Ambiental e Sanitária, Faculdade de Engenharia Ambiental da Rede de Ensino Doctum, Juiz de Fora: Centro de Engenharias Presidente Itamar Franco.

Lira, T. M., \& Chaves, M. P. S. R. (2016). Comunidades ribeirinhas na Amazônia: organização sociocultural e política. Interações, 17(1).

Medeiros, H. S., \& Forte, S. H. A. C. (2019). Influência da Corrupção Percebida na Legitimidade das Ações Públicas. São Paulo: XLIII EnANPAD.

Merriam, S. B., \& Tisdell, E. J. (2016). Qualitative research: a guide to design and implementation (4th ed.). Jossey-Bass: A Wiley Brand.

Obicci, P. A. (2016). Ethics, Corruption and Performance in Developing Economies Public Service. International Journal of Research in Management, Science \& Technology, 4(2).

Penha, T. V. (2019). Detecção de áreas queimadas na Amazônia utilizando imagens de média resolução espacial, técnicas de Geobia e mineração de dados. Dissertação Mestrado em Sensoriamento Remoto, São José dos Campos: Instituto Nacional de Pesquisas Espaciais.

Rayamajhee, V., \& Joshi, A. (2018). Economic trade-offs between hydroelectricity production and environmental externalities: A case for local externality mitigation fund. Renewable Energy, 129. https://doi.org/10.1016/j.renene.2018.06.009

Rolim, D. C. (2018). O trabalho profissional dos assistentes sociais em uma realidade amazônica: atuação nos CRAS da área urbana e rural. Vitória: XVI Encontro Nacional de Pesquisadores em Serviço Social.

Santos, D., Mosaner, M., Danielle, C., Moura, R., \& Veríssimo, A. (2018). Índice de Progresso Social na Amazônia brasileira: IPS Amazônia 2018. Belém: Imazon, Social Progress Imperative.

Saunders, M., Lewis, P., \& Thornhill, A. (2016). Research Methods for Business Students (7th ed.). Essex, England: Pearson.

Scharmer, C. O. (2019). Teoria U: como liderar pela percepção e realização do futuro emergente. Rio de Janeiro: Alta Books.

Scharmer, O. (2018). The Essentials of Theory $U$ : core principles and applications. San Francisco, CA: Berrett-Koehler Publishers.

Scharmer, O. (2020). Social Systems as If People Mattered Response to the Kühl Critique of Theory U. Journal of Change Management. https://doi.org/10.1080/14697017.2020.1744884

Silva, H. R. O., Silva, C. P. G., \& Cavalcante, M. M. A. (2019). Unidade de Conservação e Desmatamento na Amazônia: análise do Parque Estadual de Guajará Mirim em Rondônia/Brasil. ACTA Geográfica, 13(32).

Silva, L. F., Cunto, G. C., \& Guevara, A. J. H. (2016). Consumidor ou cidadão: um estudo sobre as externalidades negativas no consumo de energia. Revista de Gestão Ambiental e Sustentabilidade, 5(2).

Soares, M. L. Q. (2017). Tensão entre os discursos da razão instrumental da globalização e da razão política do estado constitucional. Revista do Direito de Língua Portuguesa, Ano V. 
Sodré, G. R. C., Souza, E. B., Oliveira, J. V., \& Moraes, B. C. (2018). Cálculo de Risco e Detecção de Queimadas: uma análise na Amazônia Oriental. RBCIAMB, 49.

Souza, F. J. B., Midlej e Silva, S. A., \& Gomes, A. O. (2019a). Corrupção no Setor Público: agenda de pesquisa e principais debates a partir da literatura internacional. Administração Pública e Gestão Social, 11(3).

Souza, G. C., Almeida, M. R. N., Nascimento, E. S., Moreira, W. C. L., \& Silva, S. S. (2019b). Interação entre os incêndios florestais e desmatamento no Alto Juruá, Acre-Brasil. Santos: XIX Simpósio Brasileiro de Sensoriamento Remoto.

Theiss, V., Dal Vesco, D. G., Utzig, M. J., \& Scarpin, J. E. (2015). Despesas públicas e externalidades positivas: uma análise da saúde dos países da américa central, do sul e México. Revista Evidenciação Contábil \& Finanças, 3(1).

Tinti, D. L. (2014). Teoria U e programação neolinguística: acessando o poder de presenciar. Revista Global Manager, 14(1).

Valdiones, A. P. G., \& Thuault, A. (2017). Transparência das informações ambientais na Amazônia Legal. Mato Grosso: Transparência Florestal: Mato Grosso, 8(5).

Yin, R. K. (2014). Case study research: Design and methods (5th ed.). Thousand Oaks, CA: Sage.

\section{Copyrights}

Copyright for this article is retained by the author(s), with first publication rights granted to the journal.

This is an open-access article distributed under the terms and conditions of the Creative Commons Attribution license (http://creativecommons.org/licenses/by/4.0/). 